\title{
Molecular and physiological characterization of indigenous copper- resistant bacteria from Cikapundung River, West Java, Indonesia
}

\author{
WAHYU IRAWATI ${ }^{1, \bullet}$, NOMMENSEN PANGIHUTAN OMPUSUNGGU ${ }^{1}$, DWI NINGSIH SUSILOWATI ${ }^{2}$, \\ TRIWIBOWO YUWONO \\ ${ }^{1}$ Department of Biology Education, Universitas Pelita Harapan. M.H. Thamrin Boulevard 1100, Lippo Karawaci, Tangerang 15811, Banten, Indonesia, \\ "email:w.irawati3@gmail.com \\ ${ }^{2}$ Indonesian Center for Agricultural Biotechnology and Genetic Resources Research and Development. Jl. Tentara Pelajar 3A, Bogor 1611, West Java, \\ Indonesia \\ ${ }^{3}$ Department of Agricultural Microbiology, Faculty of Agriculture, Universitas Gadjah Mada. Bulaksumur, Sleman 55281, Yogyakarta, Indonesia
}

Manuscript received: 16 December 2018. Revision accepted: 13 January 2019

\begin{abstract}
Irawati W, Ompusunggu NP, Susilowati DN, Yuwono T. 2019. Molecular and physiological characterization of indigenous copper-resistant bacteria from Cikapundung River, West Java, Indonesia. Biodiversitas 20: 344-349. The use of indigenous bacteria as bioremediation agents in wastewater treatments plant is a promising solution for tackling the environmental problem. The objectives of this research were to establish the phylogenetic tree and physiological characterization of copper-resistant bacteria isolated from Cikapundung River, West Java, Indonesia. A phylogenetic tree was constructed based on 16S rDNA sequences. Physiological characterization including growth and the potency of bacterial strain for copper accumulation and copper removal was also studied. Five highly copper-resistant bacteria designated as strains CN1, CN2, CN5, CN6, and CN8 have been isolated from Cikapundung river with the MICs (Minimum Inhibitory Concentration) of $5 \mathrm{mM}-8 \mathrm{mM}$. Sequence alignment and phylogenetic analysis showed that strains CN1 and CN6 belong to Klebsiella pneumoniae with the similarity of 99\%. Meanwhile, strain CN2, CN5, and CN8 belong to Acinetobacter calcoaceticus, Acinetobacter sp. and Escherichia coli with the similarity of 99\%, 96\%, and 95\%, respectively. The highest resistant bacterial isolates were strains CN6 and CN8 with the MICs of $8 \mathrm{mM}$. The highest accumulation capability was found in strain CN1 with a total of $4.62 \mathrm{mg} / \mathrm{g}$ dry weight of cells. Meanwhile, strain CN8 demonstrated the highest copper removal with the value of $48.15 \%$.
\end{abstract}

Keywords: Copper accumulation and removal, copper-resistant bacteria, phylogenetic tree

\section{INTRODUCTION}

The disposal of heavy metals sewage due to industrial activities without processing into aquatic ecosystems has become a matter of concern in Indonesia. Cikapundung River as a part of Citarum River, West Java, Indonesia is well known as the heavy metals-contaminated site in West Java, Indonesia due to the increase of industrial activities in the surrounding area. The continuous waste disposal in aquatic environment enables heavy metals resistant bacteria to adapt and thrive in this area. Indigenous bacteria isolated from a heavy metals-contaminated site usually develop resistance mechanism to survive under stress condition and may potentially be used for bioremediation agent (Irawati et al. 2017).

The presence of heavy metals in sewage and wastewater is considered a major hazard to natural water, animals and human health. Heavy metal pollution threatens the life of the organism due to its persistence that becomes a complex environmental issue in the world. The most toxic pollutants in the environment are copper, zinc, lead, cadmium, nickel, and mercury (Dash et al. 2016; Rajbanshi 2008). The present study was focused on copper as copper is known as the highest contaminating heavy metal in Cikapundung River (Septiono et al. 2015).

Copper is a metallic element crucial for cell metabolism, however, at a high concentration above threshold level it becomes toxic for bacteria. This condition enables the bacteria to deliver copper inside the cell for micronutrient element to protect the cell against its toxicity. The widespread use of copper-containing products causes bacterial cells to be intensively exposed to copper. Some bacteria developed their adaptation mechanisms when they were exposed to toxic metals in a long time and selected them to form resistant bacteria. Under stress condition, bacteria developed resistance to face heavy metals pollutant by efflux outside the cells, transformation to a less toxic form, and bioaccumulation/biosorption (Williams et al. 2012; Bondarczuk and Piotrowska 2013).

Resistance mechanisms of bacteria to copper is useful for the application of bioremediation processes. Bioremediation is a process of utilizing bacteria for removing pollutant from the environment. Bioremediation is a natural process involving the capabilities of intrinsic bacteria to clean the environment through bioaccumulation and biosorption processes (Saranraj and Stella 2012). Thus, it was important to study the indigenous resistant bacteria isolated from a contaminated copper site for bioremediation purposes. The objectives of this research were to study the molecular and physiological characterization of copper-resistant bacteria isolated from Cikapundung River. It is anticipated that the new variant of indigenous copper-resistant bacteria maybe is used as a bioremediation agent in contaminated sites. 


\section{MATERIALS AND METHODS}

\section{Medium preparation and bacterial growth}

Bacteria were grown in Luria Bertani (LB) containing the following (per liter): tryptone $10 \mathrm{~g}$, yeast extract $5 \mathrm{~g}$, $\mathrm{NaCl} 10 \mathrm{~g}$, and glucose $0.1 \mathrm{~g}$. LB agar was made with the addition of $2 \%$ of pure agar. The medium was autoclaved at $121^{\circ} \mathrm{C}, 1 \mathrm{~atm}$, for 15 minutes before being used as growth medium. The stock solution of $1 \mathrm{M} \mathrm{CuSO}_{4}$ was added to the autoclaved medium for preparation of medium containing copper. Medium without copper was also prepared as a control. Cells were grown in LB medium and incubated at $37^{\circ} \mathrm{C}$ with shaking at $150 \mathrm{rpm}$. Growth was monitored by measuring optical density at $600 \mathrm{~nm}$ using a spectrophotometer.

\section{Isolation and characterization of copper-resistant bacteria}

Isolation and characterization were carried out to obtain the highest copper-resistant bacteria. Wastewater sample was collected from the Cikapundung River, West Java, Indonesia. The samples were serially diluted as follows: $10^{-}$ ${ }^{1}, 10^{-2}, 10^{-3}, 10^{-4}, 10^{-5}, 10^{-6}, 10^{-7}, 10^{-8}, 10^{-9}$, and $10^{-10}$. Then, $100 \mu \mathrm{L}$ volume of each sample dilution was spread on LB agar medium supplemented with various concentration of copper. After an incubation period at $37^{\circ} \mathrm{C}$ for 48 hours, colonies grew on medium with the highest level of copper were selected. Each colony was purified to obtain a single colony by streaking on an agar plate. The colony morphology of bacterial isolates was observed including the form, color, margin, and elevation of the colonies. The cells morphology and Gram staining result were also observed using a light microscope (CarlZeiss).

\section{Minimum inhibitory concentration of heavy metals of the isolate}

Minimum Inhibitory Concentration (MIC) of the isolates to copper was determined by streaking the cells on the agar plates until it did not form a colony. The initial concentration added in the medium was $1 \mathrm{mM}$ of copper. The growing colonies at a given concentration were subsequently transferred to the next higher concentration. MIC was determined after 48 hours of incubation at $37^{\circ} \mathrm{C}$.

\section{Phylogenetic characterization of copper-resistant bacteria}

A phylogenetic tree was constructed based on $16 \mathrm{~S}$ rDNA sequences. Each isolate was grown in LB medium with shaking at $150 \mathrm{rpm}$ and incubated at $37^{\circ} \mathrm{C}$. Cells were collected by centrifugation at $13000 \mathrm{rpm}$ for $2 \mathrm{~min}$, and DNA was extracted by using the Wizard DNA genomic extraction kits (Promega). Quality and quantity of the DNA were determined by using nanodrops and gel electrophoresis on a $0.8 \%$ agarose gel. DNA amplification was carried out by PCR using universal primers in the position of 16S-27F (5'AGAGTTTGATCCTGGCTCAG3') and 16S-1492R (5'GGTTACCTTGTTACGACTT3') primers. DNA sequences were edited and made contig between two sequences then the sequences were analyzed by using ChromasPro. The sequence results were aligned and the similarity of each base sequence was performed on the
GenBank database by using the Classifier tool (http://rdp.cme.msu.edu) of the RDP-II database (Cole et al. 2009). Sequence alignment and phylogenetic reconstruction were performed using MEGA 6 software using Muscle (Tamura et al. 2013).

\section{Copper biosorption and accumulation}

Cells were grown in LB broth containing $3 \mathrm{mM}$ of $\mathrm{CuSO}_{4}$ and incubated at $37^{\circ} \mathrm{C}$ with shaking at $150 \mathrm{rpm}$. Cells were collected by centrifugation at $5000 \mathrm{~g}$ for $20 \mathrm{~min}$ to separate it from the growth medium. Cells were dried at oven $70^{\circ} \mathrm{C}$ for determination of dry weight and total copper content. Both cells and supernatant separately were disrupted with $\mathrm{HNO}_{3}$ at $100^{\circ} \mathrm{C}$. Copper content was determined by using atomic absorption spectrophotometer at $324.9 \mathrm{~nm}$.

\section{RESULTS AND DISCUSSION}

\section{Isolation and characterization of copper-resistant bacteria}

Five highly copper-resistant bacteria designated as strains CN1, CN2, CN5, CN6, and CN8 have been isolated from Cikapundung river with the MICs (Minimum Inhibitory Concentration) of $5 \mathrm{mM}-8 \mathrm{mM}$. Physiological characteristics of copper-resistant bacteria are shown in Table 1. All isolates were Gram-negative bacteria as reported in the previous study in Rungkut-Indonesia and Krishna-Godavari basin-Bengal. The majority of indigenous bacteria isolated from those sites were Gramnegative. Meanwhile, Keramati et al. (2011) explained that Gram-positive bacteria had no tolerance to heavy metals. Gram-positive bacteria that have been successfully isolated were only around 20\% (Irawati et al. 2017; Gunaseelan and Ruban 2011). Gram-negative bacteria more resistant to copper than Gram-negative bacteria suggests that the outer membrane of gram-negative bacteria consists of a strong negative charge such as carboxyl, amine, hydroxyl, phosphate and sulfhydryl groups which have function to bind positively charged cationic metals (Scott et al. 1990; Tortora et al. 2005).

It is shown that bacterial communities consisted of some different colonies grew on medium containing $4 \mathrm{mM}$ of copper, suggesting that Cikapundung River was contaminated by the high concentration of copper (Figure 1). Most of the colonies were white, and the remaining was light yellow (Figure 2). Irawati et al. (2016) reported that the high level of heavy metals was very toxic for bacteria. High concentration of heavy metals decreased number and kind of bacterial growth and selected it to form resistant bacterial strains. According to Habi and Daba (2009), the high concentration of heavy metals above threshold levels has a deleterious impact on the microbial communities so each bacterium may develop resistance to survive in this condition. MIC test was done on selected single colonies to determine the level of copper resistance of each bacterial isolate. From this study, five copper-resistant bacteria were successfully isolated from Cikapundung River with the MICs of $7 \mathrm{mM}-8 \mathrm{mM}$. Two highest copper-resistant bacteria were of strain CN6 and CN8 with the MIC of $8 \mathrm{mM}$. 
Table 1. Physiological characteristics of copper-resistant bacteria isolated from Cikapundung River, West Java, Indonesia

\begin{tabular}{llcl}
\hline $\begin{array}{c}\text { Bacterial } \\
\text { strains }\end{array}$ & $\begin{array}{c}\text { Gram } \\
\text { staining }\end{array}$ & $\begin{array}{c}\text { MICs of } \\
\text { copper }(\mathbf{m M})\end{array}$ & Colony color \\
\hline CN1 & Negative & 7 & White \\
CN2 & Negative & 6 & White \\
CN5 & Negative & 7 & Light yellow \\
CN6 & Negative & 8 & White \\
CN8 & Negative & 8 & Yellow \\
\hline
\end{tabular}

Molecular characterization of copper-resistant bacteria

Molecular characterization of copper-resistant bacteria based on $16 \mathrm{~S}$ rDNA showed that the isolated bacteria from Cikapundung River belonged to Klebsiella pneumoniae, Acinetobacter sp., Acinetobacter calcoaceticus, and Escherichia coli (Figure 3).

Sequence alignment and percentage of homology showed that strains $\mathrm{CN} 1$ and CN6 belonged to Klebsiella pneumoniae with the similarity of $99 \%$. Meanwhile strain $\mathrm{CN} 2, \mathrm{CN} 5$, and CN8 belong to Acinetobacter calcoaceticus, Acinetobacter sp. and Escherichia coli with the similarity of $99 \%, 96 \%$, and $95 \%$, respectively (Table 2).

Previous studies demonstrated growth characteristics of genus Acinetobacter and Klebsiella in medium supplemented with copper. Williams et al. (2016) reported that Acinetobacter sp. exhibited resistance to copper by increasing the growth in stationary phase as the adaptation mechanism in high concentrations of copper. Rensing and Grass (2003); Shah et al. (2014); Irawati et al. (2016) reported that Escherichia coli, Klebsiella pneumoniae strain IFCu4 and Acinetobacter sp. IrC1 were able to tolerate copper due to the presence of $\operatorname{cop} A$ gene which expressed as a resistance mechanism.

Previous studies reported that Klebsiella sp., Acinetobacter sp., and Escherichia coli were indigenous heavy metals resistant bacteria isolated from some contaminated sites. Three strains belonged to Klebsiella sp. isolated from diesel-polluted soils were resistant to chromium, cadmium, and copper (Aransiola et al. 2018). Acinetobacter sp. isolated from oil-polluted Aconcagua river showed resistance to copper or cadmium (Mendez et al. 2017). Meanwhile, Acinetobacter sp. IrC2 isolated from industrial sewage, Rungkut-Indonesia demonstrated multiple resistance to copper, cadmium, mercury, lead, and zinc (Irawati et al. 2015).

The presence of Escherichia coli and Klebsiella sp. in the samples obtained from the Cikapundung river suggests that, in addition to copper contamination, the river is also contaminated with fecal sewage. Despite the fact that $E$. coli isolated in this study demonstrated only $96 \%$ homology with the database, yet the presence of other fecal bacteria, Klebsiella sp. which is present in the gastrointestinal tract as $E$. coli, supports the observation that $E$. coli are also a common contaminating bacterium in the water body, particularly river in Indonesia.

\section{Growth characteristic of copper-resistant bacteria}

The growth of bacterial strain from Cikapundung in medium without copper and medium supplemented with 3 $\mathrm{mM}$ of copper demonstrated the best growth in medium without copper were strain CN6 and CN8 (Figure 4). Meanwhile, the best growth in medium containing $3 \mathrm{mM}$ of copper was strain CN1. The presence of copper declined the growth of bacterial strain even though they experienced the log phase similar to that of in medium without copper. Brahmaprakash et al. (1988) reported that the ability of bacteria to reach the log phase suggested that the bacteria had resistance to copper. The ability to grow in specific copper concentration can be used to determine the MIC of the bacterial strain. In this study, strain $\mathrm{CN} 1$ demonstrated the best growth when it was cultivated in medium supplemented with $3 \mathrm{mM}$ of copper. Other bacterial strains, however, showed comparable growth.

Table 2. Phylogenetic characteristics of copper-resistant bacteria isolated from Cikapundung River, West Java, Indonesia

\begin{tabular}{lll}
\hline $\begin{array}{l}\text { Bacterial } \\
\text { Strains }\end{array}$ & Species & \% similarity \\
\hline CN1 & Klebsiella pneumoniae & $99 \%$ \\
CN2 & Acinetobacter calcoaliticus & $99 \%$ \\
CN5 & Acinetobacter sp. & $96 \%$ \\
CN6 & Klebsiella pneumoniae & $99 \%$ \\
CN8 & Escherichia coli & $96 \%$ \\
\hline
\end{tabular}

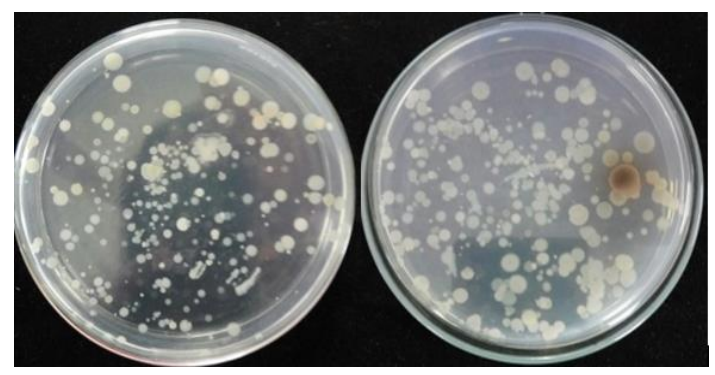

Figure 1. Bacterial communities isolated from Cikapundung River, West Java, Indonesia grew on medium containing $4 \mathrm{mM}$ of copper

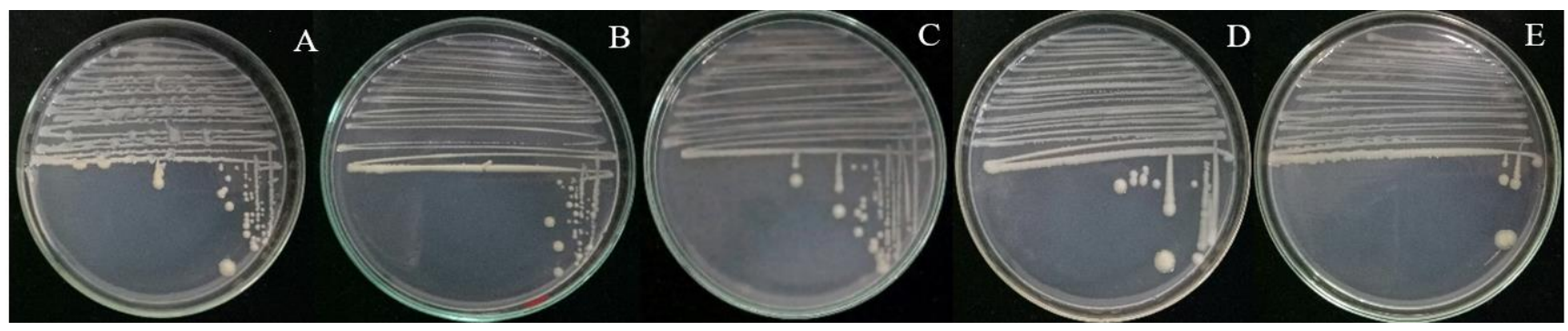

Figure 2. Colonies morphology of bacterial strains from Cikapundung River, West Java, Indonesia in medium containing $4 \mathrm{mM}$ of copper. (A-E: Strain CN1, CN2, CN5, CN6, and CN8, respectively) 


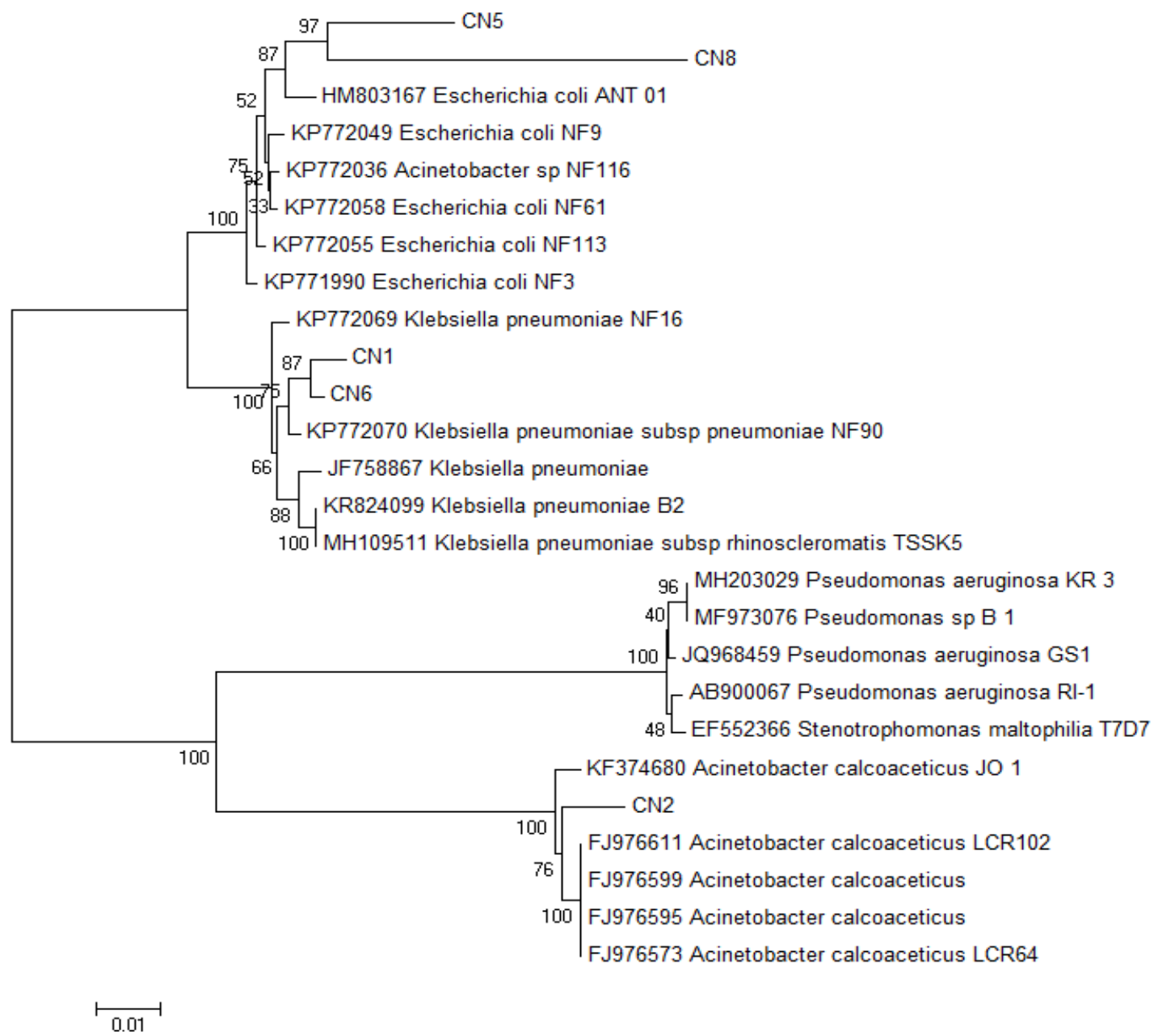

Figure 3. Phylogenetic tree of bacterial strain based on 16s rDNA sequences using the Neighbor-Joining method

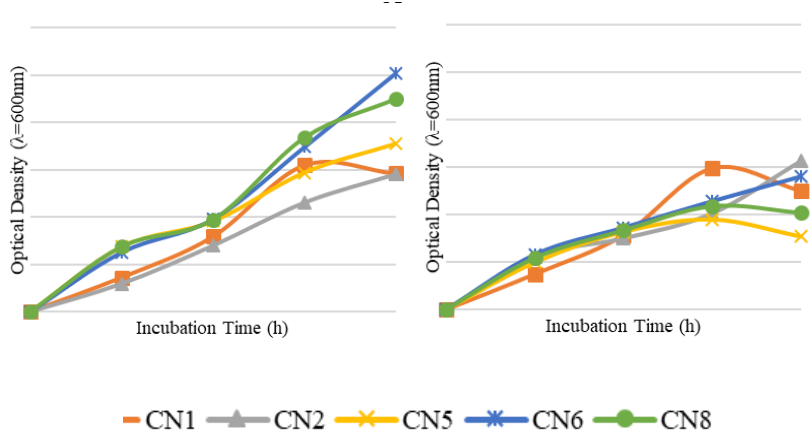

A

B

Figure 4. The growth of bacterial strain from Cikapundung River, West Java, Indonesia in medium without copper and medium supplemented with $3 \mathrm{mM}$ of copper.

Copper is an essential heavy metal required for growth and development of bacteria and plays a role as co-factors for metalloproteins and enzymes. However, at high concentration, copper has a detrimental effect on the bacterial communities (Ahemad and Malik 2012; Nies 1999). Pereira et al. (2012) and Li et al. (2004) reported that inhibition of growth occurred as a result of alteration in enzymes specificity and the conformation structure of proteins required in metabolism processes. Copper exerts an inhibitory action on bacteria by blocking essential groups or modifying the active conformations of biological molecules. To protect the cells from the toxic effect of copper, bacteria developed resistance mechanisms by absorbing copper inside the cells at the appropriate concentration required as a micronutrient. This mechanism is called bioaccumulation, or biosorption processes, a process of intracellular metal accumulation by living cells. Biosorption can bind heavy metallic species to live cells, inert biomass or to a microbial extracellular polymer (da Silva Oliveira et al. 2007).

\section{Copper accumulation and copper biosorption}

The highest accumulation capability was strain $\mathrm{CN} 1$ followed by strain CN6 with a total of 4.62 and $3.12 \mathrm{mg} / \mathrm{g}$ dry weight of cells, respectively (Figure 5). This result is consistent with Figure 5 in that, and strain $\mathrm{CN} 1$ was the best growth on medium containing copper. It was suggested that in this toxic condition, the strains developed resistance mechanism by secretion of exopolymer as a chelating agent for binding copper. Strains CN1 and CN6 
had different characteristics of colony morphology compared to the other strains when were grown on medium supplemented with $6 \mathrm{mM}$ of copper as they showed slimmer colonies than others (Figure 5). According to Pushkar et al. (2015), exopolymer secretion is one of bacterial resistance mechanism to survive in heavy metals-contaminated sites.

Based on MICs test and their capabilities to accumulate copper, strains CN6 and CN8 were the two highest copperresistant bacteria and copper accumulation. This result may be explained by the fact that its intrinsic characteristic capable of secretion of exopolymer contributes to the binding heavy metals as the resistance mechanism as presented in Figure 6. According to Vicentin et al. (2018), in some strains, the presence of heavy metals induced production of exopolymer for heavy metals complexation extracellularly. Kavamura and Esposito (2010) reported that some resistant bacteria produced exopolymer as a chelating agent for binding heavy metals as a form of adaptation and tolerance mechanism to reduce the toxicity of heavy metals.

The potency of bacterial strain for copper biosorption in medium containing $3 \mathrm{mM}$ of copper is presented in Figure 7. Strain CN8 following by strain CN6 were the two highest bacterial strains for copper removal with a total of $48,15 \%$ and $36.78 \%$, respectively. This is similar with physiological characteristics of bacterial strains in Table 1 that, strain CN6 and strain CN8 were the two highly copper-resistant bacteria with the MIC of $8 \mathrm{mM}$. Biosorption was reported to be a potential strategy for copper removal and reducing its concentration until reaching the accepted minimum concentration. Bacteria was reported to not only remove copper but also various types of heavy metals both in batch and continuous processes (Colak et al. 2013).

In conclusion, from this study, indigenous copperresistant bacteria from Cikapundung River, identified as Klebsiella pneumoniae, Acinetobacter calcoaceticus, Acinetobacter sp., and Escherichia coli, were obtained. It is interesting to note that all four isolates demonstrating high copper resistance are Gram-negative bacteria. These bacterial strains are promising candidate as bioremediation agents as they highly resistant to copper and had capabilities to biosorp up to $48.15 \%$ and accumulate copper up to $4.62 \mathrm{mg} / \mathrm{g}$ dry weight of cells.

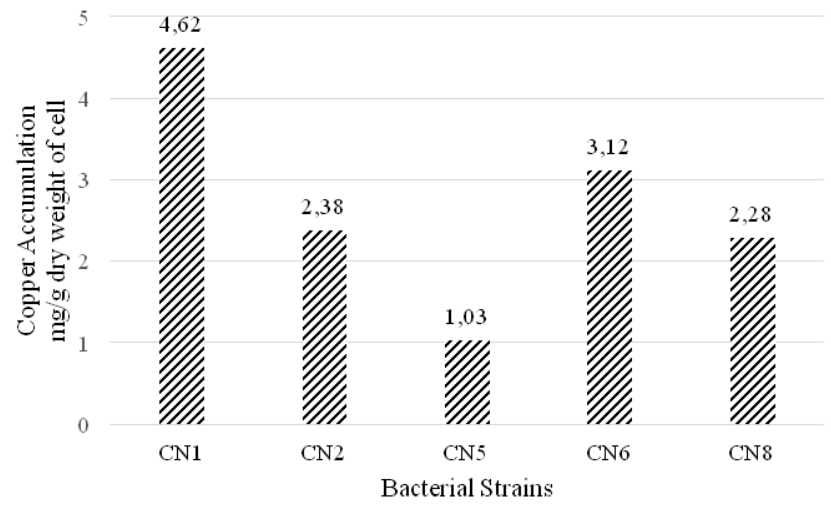

Figure 5. Copper accumulation of bacterial strain from Cikapundung River, West Java, Indonesia in medium containing 3 $\mathrm{mM}$ of copper

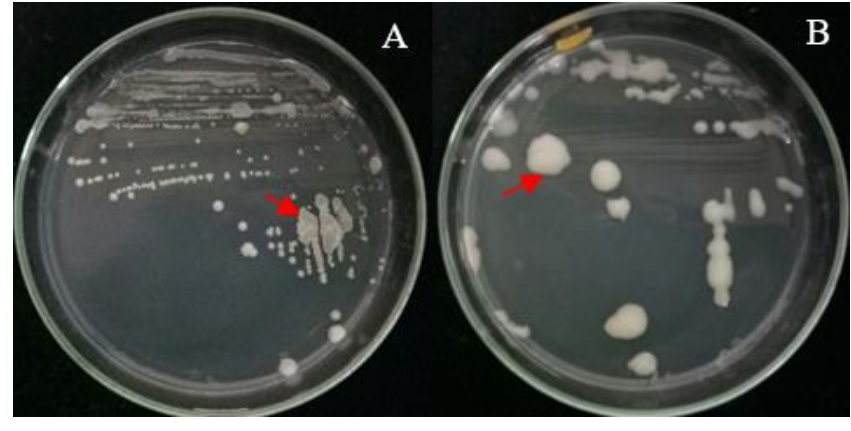

Figure 6. Appearances of the bacterial strain in a medium containing $6 \mathrm{mM}$ of copper. A. Strain CN1. B. Strain CN6. The arrows point to bacterial isolate

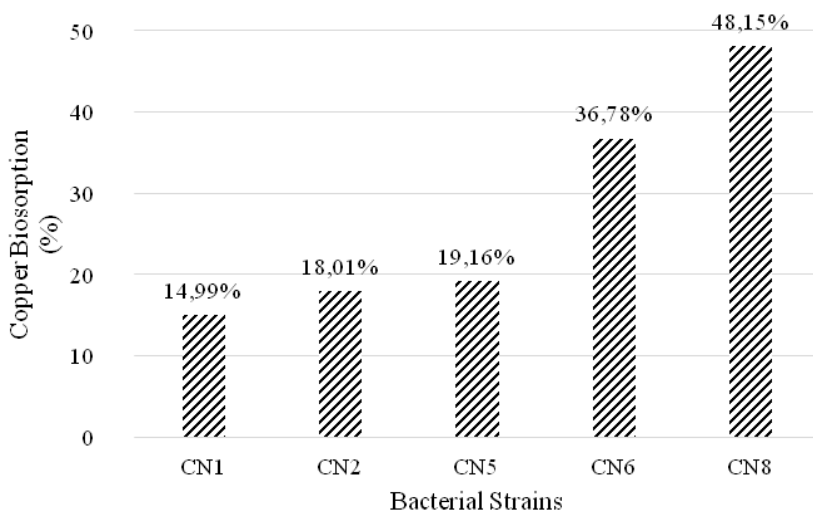

Figure 7. Copper biosorption percentage of bacterial strain in medium containing $3 \mathrm{mM}$ of copper

\section{ACKNOWLEDGEMENTS}

This research was funded by Ministry of Research and Higher Education, the Republic of Indonesia through the project of Produk Terapan (Penelitian Strategis Nasional Institusi) year 2018, contract number 135/LPPMUPH/IV/2018. The authors would also like to thank Pebrianti and Grace Charity Mary, students of the Biology Department, Teachers College, Universitas Pelita Harapan for their assistance in accomplishing this project.

\section{REFERENCES}

Ahemad M, Malik A. 2012. Bioaccumulation of heavy metals by zinc resistant bacteria isolated from agricultural soils irrigated with wastewater. Bacteriol J 2 (1): 12-21.

Aransiola EF, Ige OA, Ehinmitola EO, Layokun SK. 2017. Heavy metals bioremediation potential of Klebsiella species isolated from diesel polluted soil. Afr J Biotechnol 16 (19): 1098-1105.

Bondarczuk K, Piotrowska-Seget Z. 2013. Molecular basis of active copper resistance mechanisms in Gram-negative bacteria. Cell Biol Toxicol 29: 397-405.

Brahmaprakash GP, Devasia P, Jagadish KS, Natarajan KA, Rao RG. 1988. Development of Thiobacillus ferrooxidans ATCC 19859 strains tolerant to Copper and zinc. In: Bull Mater Sci 10 (5): 461-465.

Colak F, Olgun A, Atar N, Yazicioglu D. 2013. Heavy metal resistance and biosorptive behavior of Paenibacillus polymixa: batch and column studies. J Ind Eng Chem 19 (3): 863-869. 
Cole JR, Wang Q, Cardenas E, Fish J, Chai B, Farris RJ, Kulam-SyedMohideen AS, McGarrell DM, Marsh T, Garrity GM, Tiedje JM 2009. The Ribosomal Database Project: improved alignments and new tools for rRNA analysis. Nucleic Acids Res 37: 141-5.

Da Silva Oliveira A, Bocio A, Trevilato TMB. 2007. Heavy metals in untreated/treated urban effluent and sludge from a biological wastewater treatment plant. Environ Sci Pollut Res Intl 14 (7): 483 489.

Das S, Dash HR, Chakraborty J. 2016. Genetic basis and importance of metal resistant genes in bacteria for bioremediation of contaminated environments with toxic metal pollutants. Appl Microbiol Biotechnol 100: 2967-2984

Gunaseelan C, Ruban P. 2011. Heavy metal resistance bacterium isolated from Krishna-Godavari basin, Bay of Bengal. Int J Environ Sci 1 (7) 1864-1872.

Habi S, Daba H. 2009. Plasmid incidence, antibiotic and metal resistance among Enterobacteriaceae isolated from Algerian streams. Pak J Biol Sci 12: 1474-1482.

Irawati W, Kusumawati L, Sopiah RN. 2015. The potency of Acinetobacter $\mathrm{sp}$. $\mathrm{IrC} 2$ isolated from industrial wastewater treatment plant in Rungkut-Surabaya as a bioremediation agent for heavy metals. Asian J Microbiol Biotechnol Environ Sci 17 (1): 1-7.

Irawati W, Wijaya Y, Christian S, Djojo ES. 2016. Characterization of heavy metals resistant yeast isolated from activated sludge in Rungkut, Surabaya, Indonesia as biosorbent of mercury, copper, and lead. AIP Conference Proceedings 1744, 020061-1-9. DOI $10.1063 / 1.4953535$

Irawati W, Yuwono T, Rusli A. 2016. Detection of Plasmids and Curing Analysis in Copper Resistant Bacteria Acinetobacter sp. C1, Acinetobacter sp. C2, and Cupriavidus sp. C4. Biodiversitas 17 (1) 296-300.

Irawati W, Riak S, Sopiah N, Sulistia S. 2017. Heavy metal tolerance in indigenous bacteria isolated from the industrial sewage in Kemisan River, Tangerang, Banten, Indonesia. Biodiversitas 18 (4): 14811486.

Kavamura VN, Esposito E. 2010. Biotechnological strategies applied to the decontamination of soils polluted with heavy metals. Biotechno Adv 28 (1): 61-69.

Keramati P, Hoodaji M, Tahmourespour A. 2011. Multi-metal resistance study of bacteria highly resistant to mercury isolated from dental clinic effluent. Afr J Microbiol Res 5 (7): 831-837.

Li Q. Wu S, Liu G, Liao X, Deng X, Sun D, Hu Y, Huang Y. 2004. Simultaneous biosorption of Cadmium (II) and lead (II) ions by pretreated biomass of Phanerochaete chrysosporium. Sep Purif Technol 34: 135-142.
Méndez V, Fuentes S, Morgante V, Hernández M, González M, Moore E. Seeger M. 2017. Novel hydrocarbonoclastic metal-tolerant Acinetobacter and Pseudomonas strains from Aconcagua river oilpolluted soil. J Soil Sci Plant Nutr 17 (4): 1074-1087.

Nies DH. 1999. Microbial heavy metal resistance. Appl Microbiol Biotechnol 51: 730-750.

Pereira F, Krishnan KP, Sinha RK, Kerkar S. 2012. Insights on metalmicrobe interactions Bacillus sp. and Chromohalobacter sp. from a solar saltern. J Ecobiotechnol 4 (1): 14-24.

Pushkar BK, Sevak PI, Singh A. 2015. Isolation and characterization of potential microbe for bio-remediating heavy metal from Mithi river. Ann Appl Bio-sci 2 (2): 1-27

Rajbansh. 2008). Study on heavy metal resistant bacteria in Guheswori sewage treatment plant. Our Nat 6: 52-57.

Rensing C, Grass G. 2003. Escherichia coli mechanisms of copper homeostasis in a changing environment. FEMS Microbiol Rev 27 197-213.

Saranraj P and Stella D. 2012. Bioremediation of sugar mill effluent by immobilized bacterial consortium. Intl J Res Pure Appl Microbiol 2 (4): 43-48.

Scott JA, Palmer SJ. 1990. Sites of cadmium uptake in bacteria used for biosorption. Appl Microbiol Biotechnol 33 (2): 221-225.

Septiono MA, Roosmini D. 2015. Heavy metal distribution in water, sediment, and fish at upper Citarum river and its potential exposure pathway to human. The 5th Environmental Technology and Management Conference "Green Technology towards Sustainable Environment" November 23- 24, 2015, Bandung, Indonesia.

Shah R, Patel J, Prasad BD, Kumar P. 2014. The P-type ATPase Mediates copper tolerance in Klebsiella pneumoniae IFCu4 strain isolated from south Gujarat industrial effluents. J Pharm Appl Sci 1 (1): 1-7.

Tamura K, Stecher G, Peterson D, Filipski A, Kumar S. 2013. MEGA 6: Molecular evolutionary genetics analysis version 6.0. Mol Biol Evol 30: 2725-2729.

Tortora GJ, Funke DR, Case CL. 2005. Microbiology: An Introduction, 8th ed. Pearson Education Inc., San Fransisco, CA.

Vicentin RP, dos Santos JV, Labory CRG, da Costa AM, Moreira FMS, Alves E. 2017. Tolerance to accumulation of cadmium, copper, and zinc by Cupriavidus necator. Rev Bras Cienc Solo 42: e0170080. DOI: $10.1590 / 18069657 \mathrm{rbcs} 20170080$.

Williams GP, Gnana design M, Ravikumar S. 2012. Biosorption and biokinetic studies of halobacterial strains against $\mathrm{Ni}^{2+}, \mathrm{Al}^{3+}$, and $\mathrm{Hg}^{2+}$ metal ions. Bioresour Technol 107: 526-529.

Williams CL, Neu HM, Gilbreath JJ, Michel SLJ, Zurawski DV, Merrella DS. 2016. Copper Resistance of the Emerging Pathogen Acinetobacter baumannii. Appl Environ Microb 82 (20): 6174-6188. 